\title{
Analysis of Forest Cover Changes in Nimbia Forest Reserve, Kaduna State, Nigeria using Geographic Information System and Remote Sensing Techniques
}

\author{
Musa Ismaila Tudun-Wada ${ }^{1}$, Yakubu Mohammed Tukur², Ya'U Hussaini² Muhammad Zakari Sani ${ }^{1}$, Ishaya \\ Musa $^{3}$ and Vivan Ezra Lekwot ${ }^{4}$ \\ 1, Forestry Technology Department, Federal College of Forestry, Jos, Nigeria \\ 2, Basic Science And General Studies Department, Federal College of Forestry, Jos, Nigeria. \\ 3, Department Of Pest Management Technology, Federal College of Forestry, Jos, Nigeria. \\ 4, Department Of Geography And Planning, University of Jos, Nigeria \\ *Corresponding Author Email Address: ezravivan@yahoo.com, ezrav540@gmail.com.
}

\begin{abstract}
Nimbia Forest Reserve is witnessing degradation due to anthropogenic activities such as Farming, Illegal felling and fuel wood extraction just like many other forest reserves in Nigeria. On the other hand, the management has failed to provide enough manpower to guard against anthropogenic activities and the few ones available were not receiving better remuneration. Other problems faced by the forest are that trimming is done on time and cleared lands were not replanted. These and many other reasons leading to overexploitation, increase rate of deforestation, modification of the forest structure, reduced income to government and increased unemployment. This study examines the use of GIS and Remote Sensing in mapping Land Cover in Nimbia Forest Reserve between 1986 and 2010 so as to detect the changes that may have taken place in this status between these periods. Subsequently, an attempt was made at projecting the observed land cover in the next 21 years. The result obtained show that some features will be lost to other features and possible reasons for that were evaluated.

Suggestions were therefore made at the end of the work on ways to use the information as contained therein optimally.
\end{abstract}

Keywords: Landcover Change, Forest, Geographic Information System, Remote Sensing, Landsat Satellite Imagery

\section{INTRODUCTION}

Forests over history have value to the world's human population and their value is by each day increasing as people still used forest to protect themselves to shelter and for fuel wood. According to Misir (1997), beside raw material for wood processing industry that forest provides, forest provide habitat for wildlife, reserves for water and soil conservation, oxygen and food chain. However, our forest is facing so many problems. Most of the world's vegetation is in a constant state of flux at a variety of spatial and temporal scale, deforestation of our tropical forest is a result of many pressures (Lambin,1996). As people tried to meet their daily needs, they are subjecting forest, woodland and grassland to the highest rate of change (Pomery, 2004). Also as noted by Tudunwada (2012), our forest today is faced with all sorts of anthropogenic activities, such as, illegal felling of trees for firewood and roofing, illegal cultivation and conversion of parts of the forest for residential by nomads. In a world with an increasing population and also increased pressure on our natural and man-made forest resources, there is a greater demand for up-to-date and accurate spatial information. Geographic Information System (GIS) and Remote Sensing (RS) are now providing new tools for advance ecosystem management. Lunette (1999) stated that; the use of RS and GIS techniques allows the extent of change in our vegetation to be easily analyzed. Vegetation change detection is useful in land use and land cover changes, wildlife extinction, rate of deforestation. Afforestation effect and other cumulative changes through spatial and temporal analysis techniques. Therefore, attempt will be made in this study to map out the status of Nimbia Forest Reserve between 1986 to 2010 with a view to detecting the change that has taken place and also predict possible changes that might take place in this status in the next 30 years using GIS and RS data.

Before the current Nimbia forest reserve was established there was a natural forest which was cleared in 1957and replaced by the government with exotic species mainly Teak (Tectona grandis) and a few Gmelinaarboreastands. The purpose was to raise a logging plantation that could serve as a source of employment to the youth of the area and a source of revenue to the government. Contrary to this, the Forest is facing some level of degradation as a result of the nonchalant attitude of the management and illegal poaching currently going on in the forest. Some of the problems being faced by the forest are: logging of premature stands without replacing since 1991, inadequate manpower at the forest camp to guard the forest against illegal activities such as: illegal felling, setting bush fire, cultivation and encroach. Regenerated trees were left unattended due to shortage of manpower to handle the trimming. Similarly, most of the workers were employed 
on casual basis receiving poor remuneration, thus, this encourages them to franchise the harvested plots for farming to nearby villagers instead of replanting and they also connive with illegal fellers to obtain timbers in exchange for money.

\section{Aim and Objectives}

The aim of this study is to use multi-temporal Landsat imageries for the past 24 years (1986-2010) to determine the spatio-temporal dynamics of the changes in Nimbia Forest Reserve.

The following specific objectives will be pursued in order to achieve the aim of the study.

(i) To generate land cover maps of the forest structures for the period 1986, 1998 and 2010.

(ii) To determine the magnitude and percentage change of the forest cover that occurred over the study periods.

\section{The Study Area}

(iii) To forecast the future forest cover of the study area.

\section{Geographical location and Extent}

Nimbia Forest Reserve is located in the Southern Guinea Savanna Zone of Nigeria. It lies between longitudes $8^{0} 30^{\prime}$ and $8^{0} 35^{\prime} \mathrm{E}$ and latitudes $9^{\circ} 29^{\prime}$ and $9^{0} 31^{\prime} \mathrm{N}$ (see figure 1.1 ) with an elevation of about $600 \mathrm{~m}$ above sea level. The forest reserve is located in Jema'a Local Government Area of Kaduna State Seventy Kilometers South East of Jos along Jos - Kafanchan road.Nimbia Forest Reserve covers an area of about 2,282.4 hectares. It is long and narrow in shape, bounded on the South by Gimi River and on the North by the Lioc Stream(Obidike, 2011).

\section{History of the plantation}

The natural vegetation was cleared in 1957, by the then Jema'a native Authority and replaced with mainly Teak (Tectona grandis) and few gmelina arborea stands. According to Howard (1963), the first trial plantation of teak started in 1957, and between 1958 and 1966, 98.42 hectares were planted with teak. The planting continued through the seventies with the last planting carried out in 1991.

Teak (Tectona grandis Linn. F), a native of tropical and subtropical India and South East Asia. It tolerates a relatively wide range of climatic condition in areas of rainfall ranging below $762 \mathrm{~mm}$ to over $3,810 \mathrm{~mm}$ per annum at between $13^{\circ} \mathrm{c}$ and $37^{\circ} \mathrm{c}$ respectively. Nimbia Forest Reserve is located within the Jema'a platform and is underlain predominately by igneous and metamorphic rocks. The position Nimbia with respect to its altitude (600 $\mathrm{m}$ above sea level) induces orographic rain. The altitude of Nimbia Forest Reserve contributes to the lower temperatures experienced. Its minimum temperatures are as low as $12.9^{\circ} \mathrm{C}$ and $11^{\circ} \mathrm{C}$ while the maximum temperatures for the hottest month (March) is $25^{\circ} \mathrm{C}$. The highest humidity value of the reserve is obtained in July and August when the rainfall is heaviest (Ayuba, 2006).

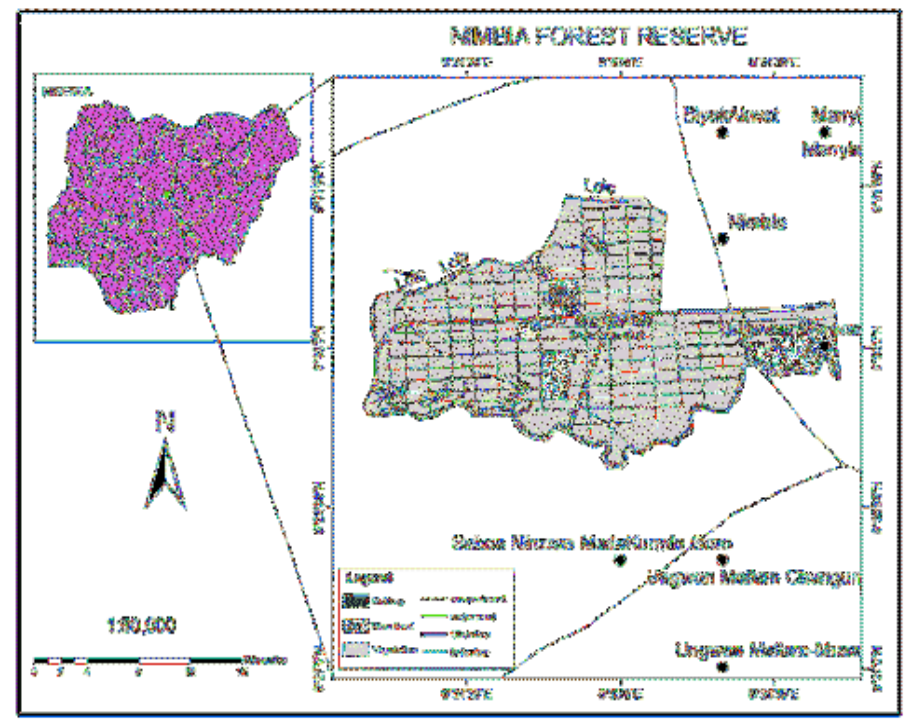

Figure. 1.1TheStudy Area

\section{MATERIALS AND METHOD}

The data used for studying Nimbia forest spatio-temporal land cover change include three historical landsat satellite images covering Nimbia forest for the past 24 years (1986-2010).The images of 1986, 1998 and 2010 with spatial resolution of 30m were obtained from Global Land Cover Facility (GLCF) an Earth Science Data Interface through the URL: http://glcfapp.glcf.umd.edu:8080/esdi/index.jsp.These data sets were captured by 
Landsat-5 TM on 17 and 18 November 1986 and 1998 respectively, while the other Landsat ETM was captured on 21 December 2010 all using WRS 2 path/row 188/53 .

Spot-5 imagery was acquired from RECTAS and it was used as a reference data for classification accuracy assessment. It was also used to delineate the topographic map of the study area as shown in Figure 1.1. Table 1 shows the characteristics of the images used for this study. November 1986 and1998 scenes were selected because of reduced spectral separability and phonological stability as was noted by Ayuba, (2006) that for any meaningful change detection, summer and winter are the best seasons because of their phonological stability. Also, selecting the summer or the driest period of the year enhances spectral separability. However, the spectral separability is reduced as a result of excessive wetness prevailing during other period of the year (Dewan, 2009).

Table 1: Attribute of the images use for the study

\begin{tabular}{|l|l|l|l|l|}
\hline Data Type & Resolution & Spectral Bands & WRS: P/R & Date of Acquisition \\
\hline Landsat TM & $30 \mathrm{~m}$ & $1,2,3,4,5$ and 7 & $188 / 054$ & $17-11-1986$ \\
\hline Landsat ETM & $30 \mathrm{~m}$ & $1,2,3,4,5$ and 7 & $188 / 054$ & $18-11-1998$ \\
\hline Landsat ETM & $30 \mathrm{~m}$ & $1,2,3,4,5$ and 7 & $188 / 054$ & $21 / 12 / 2010$ \\
\hline Spot-5 & $10 \mathrm{~m}$ & $1,2,3$ & & 2010 \\
\hline
\end{tabular}

Source: Field Survey 2010

The Global Positioning System (GPS) has developed into an efficient GIS data technology, which allows for users to compile their own data sets directly from the field as part of the 'ground truthing. In this study, point data was collected using GPS at different points in the field. This is done whenever the GPS fully acquired connection from the satellite at the selected point.

Acquired Landsat satellite imageries were individually imported into IDRISI Tiger environment by loading each layer at a time. Since the images were pre-georeferenced and orthorectified from the source, then, there was no need for that exercise again. Image window was performed using spatial analyst tool on a sub-scene from the full image on the basis of a frame covering the Forest. These pre-processing tasks allowed the satellite images for classification and extraction of land cover information.

The assessment of land use and land cover was done by adopting a classification scheme for the Landsat images for years 1986, 1998 and 2010 and carrying out a Supervised classification (Maximum likelihood) based on ancillary data and other information obtained from the field and literature sources.

Based on the knowledge acquired as result of reconnaissance survey with additional information from some staff of the forest reserve and information from previous researches in the study area, a classification scheme was developed for the study area after.

Table 2: Land cover classification scheme.

\begin{tabular}{|l|l|l|}
\hline Code & Land use/Land cover categories & Description \\
\hline 1 & Plantation & $\begin{array}{l}\text { Area predominately Gmelina arborrea and Teak(Gmelina } \\
\text { arborrea). }\end{array}$ \\
\hline 2 & Bare land & $\begin{array}{l}\text { Area dominated by growing cropping field, Experiment plots and } \\
\text { bare soils. }\end{array}$ \\
\hline 3 & Stream & Stream and river channel. \\
\hline 4 & Rock & $\begin{array}{l}\text { Areas covered by basaltic boulders, escarpment, igneous and } \\
\text { metamorphic rocks. }\end{array}$ \\
\hline
\end{tabular}

Four main methods of data analysis were adopted in this study, namely:

(i) Maximum Likelihood Classification

(ii) Calculation of the Area in hectares of the resulting land cover types for each study year and subsequently comparing the results.

(iii) Markov Chain and Cellular Automata Analysis for predicting change

(iv) Normalize Difference Vegetation Index (NDVI).

After all the necessary correction and making the images ready for classification, the bands 4,3,2 of the individual image were combined that produced a color composite for vegetation cover. Using linear enhancement module, the color composite was further enhanced. The Normalized Difference Vegetation Index (NDVI) was performed to detect areas prone to human activities. Vegetation health is estimated using NDVI and it also provides a means of monitoring changes in vegetation over time. Maximum likelihood technique and ground survey data were used to identify and classify the training sites using supervised classification. The classified images were then overlaid to determine the extent of change in the forest reserved. Image classification and interpretation was performed using IDRISI Tiger.

Using reference images (Spot-5), training samples were gathered from 30 points as signatures for each Landsat satellite images. These signatures were then used in a supervised classification method. Land use/land cover was mapped by means of visual interpretation of satellite images. The classification consists of four classes for each 
time period (Table 2). The major classes are; Plantation, Bare Land, Streams, and Bare Rock. From the supervised classification methods in IDRISI tiger, the Maximum Likelihood (ML) classification algorithm was used to produce the land cover maps. The maximum likelihood classification method uses a decision rule to evaluate each pixel. To be assigned to a particular class, a pixel must exhibit reflectance within this reflectance range for every band considered. The final land cover maps produced using these procedures enabled spatiotemporal change analysis and pattern through change maps and spatial metrics.

To achieve the second objective of this study, the study area was measured in hectares using IDRISI software by tabulating the result of the classified images obtained. The comparison of the land use/land cover statistics assisted in identifying the percentage change, trend and rate of change between 1986 and 2010. In achieving this, the first task was to develop a table showing the area in hectares and the percentage change for each year 1986, 1998 and 2010 measured against each land use/land cover type. Percentage change to determine the trend of change can then be calculated by dividing observed change by sum of changes multiplied by 100 .

(Trend) Percentage change $=\frac{\text { Observe change }}{\text { Sum of change }} \times 100$

(Zubair, 2006).

Predicting or projecting land cover change to a particular period is possible using Markov and cellular automata. These two algorithms are available in IDRISI. A Markovian process is one in which the future state of a system can be modeled purely on the basis of immediately preceding state. The Markov module analyzes a pair of land cover images and outputs a transition probability matrix, a transition area matrix, and a set of conditional probability images. The transition probability matrix is a text file that records the probability that each land cover category will change to every other category. The transition areas matrix is a text file that records the number of pixels that are expected to change from each land cover type to each other land cover type over the specified number of time unit. In both of these files, the rows represent the earlier land cover categories and the columns represent the later categories. The conditional probability images report the probability that each land cover type would be found at each pixel after the specified number of time unit. In addition to this process, Normalized Difference Vegetation Index (NDVI) was also applied to detect areas of vegetation cover decrease. This method has proved reliable in monitoring vegetation change. Vegetation differential absorbs visible incident solar radiant and reflects much of the infrared (NIR), data on vegetation biophysical characteristics can be derived from visible and NIR and MIR portions of the Electro Magnetic Spectrum (EMS). The NDVI approach is based on the fact that healthy vegetation has low reflectance in the visible portion of the EMS due to chlorophyll and other pigment absorption and has high reflectance by the mesophyll spongy tissue of green leaf. NDVI can be calculated as a sensor system; its values range from -1 to +1 . Healthy vegetation is represented by NDVIvalues between 0.1 and 1. Non vegetated surfaces such as water bodies yield negative values because of the electromagnetic absorption quality of water. Bare soil areas represent NDVI values which are closest to 0

\section{RESULTS AND DISCUSSION \\ Land cover classification and mapping forest structures}

A supervise classification using maximum likelihood algorithm was used for the three remotely sensed images and the result of the classification provides an overview of the major land cover features of Nimbia Forest Reserve for the year 1986, 1998 and 2010.The Forest is categorized by four land cover features as also identified are; plantation, Bare land, Stream, and Bare rock. These land use land cover classes were derived from images 1986, 1998, and 2007 for the study. The maps of the classified images was achieved and illustrated by figure 1, 2 and 3 for the land cover changes 1986, 1998 and 2010 respectively. 


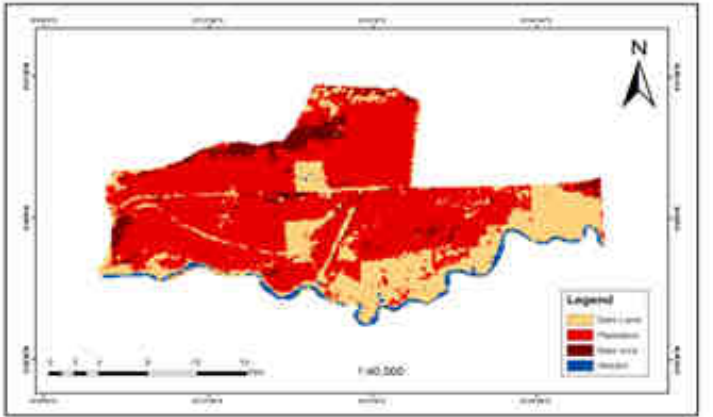

Fig 1

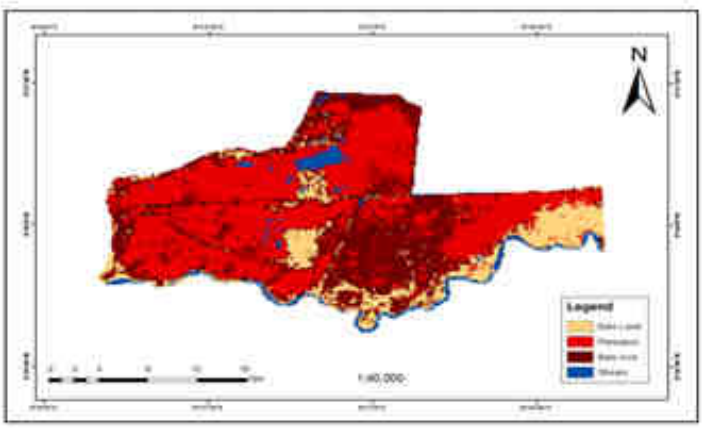

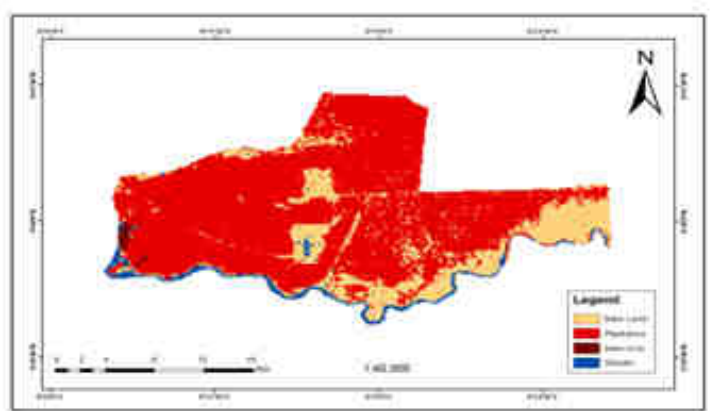

Fig 2
Fig 1 Landcover of the study area 1986

Fig 2 Landcover of the study area 1998

Fig 3 Landcover of the study area 2010

Fig 3

Land use land cover distribution

The static land use land cover distribution for each year as derived from the image maps is presented in table 3 below.

The classification results shown in table 3, indicates the land use land cover classes in year land $(27.14 \%, 20.52 \%$ and $13.88 \%)$ Stream $(2.85 \%, 3.36 \%$ and $4.43 \%)$ and Bare rock $(6.51 \%, 0.53 \%$ and $33.03 \%$ ), respectively.

Table 3 Size and proportion of land cover classes from 1986-2010

\begin{tabular}{|c|c|c|c|c|c|c|}
\hline \multirow[t]{2}{*}{ Land cover type } & \multicolumn{2}{|c|}{ Area in 1986} & \multicolumn{2}{|c|}{ Area in 1998} & \multicolumn{2}{|c|}{ Area in 2010} \\
\hline & (Ha) & $(\%)$ & $(\mathrm{Ha})$ & $(\%)$ & (Ha) & $(\%)$ \\
\hline Plantation & 1325.88 & 63.51 & 1577.97 & 75.59 & 1015.92 & 48.66 \\
\hline Bare Land & 566.55 & 27.14 & 428.31 & 20.52 & 289.71 & 13.88 \\
\hline Stream & 59.4 & 2.85 & 70.2 & 3.36 & 92.43 & 4.43 \\
\hline Bare rock & 135.81 & 6.51 & 11.16 & 0.53 & 689.58 & 33.03 \\
\hline Total & 2087.64 & 100 & 2087.64 & 100 & 2087.64 & 100 \\
\hline
\end{tabular}

Source: Field Survey 2010

Table 4 Land Use Land Cover Change: Magnitude and Percentage change

\begin{tabular}{|l|l|l|l|l|l|l|l|}
\hline \multirow{2}{*}{$\begin{array}{l}\text { Activity } \\
\text { Types }\end{array}$} & \multicolumn{2}{|l|}{ Area covered $(\mathrm{Ha})$} & $\begin{array}{l}\text { Difference } \\
(\mathrm{Ha})\end{array}$ & $\begin{array}{l}\text { Difference } \\
(\mathrm{Ha})\end{array}$ & $\begin{array}{l}\text { Increase/ } \\
\text { Decrease\% }\end{array}$ & $\begin{array}{l}\text { Increase/ } \\
\text { Decrease\% }\end{array}$ \\
\cline { 2 - 8 } & $\mathbf{1 9 8 6}$ & $\mathbf{1 9 9 8}$ & $\mathbf{2 0 1 0}$ & $\mathbf{1 9 8 6 - 1 9 9 8}$ & $\mathbf{1 9 9 8 - 2 0 1 0}$ & $\mathbf{1 9 8 6 - 1 9 9 8}$ & $\mathbf{1 9 9 8 - 2 0 1 0}$ \\
\hline Plantation & 1325.88 & 1577.97 & 1015.92 & 252.09 & -562.05 & 12.08 & -26.92 \\
\hline Bare Land & 566.55 & 428.31 & 289.71 & -138.24 & -138.60 & -6.60 & -6.64 \\
\hline Stream & 58.95 & 70.20 & 92.43 & 11.25 & 22.23 & 0.54 & 1.06 \\
\hline Bare rock & 135.81 & 11.16 & 689.58 & -124.65 & 674.42 & -5.98 & 32.31 \\
\hline
\end{tabular}

Source: Field Survey 2010

The data in tables 3 and 4 above represent information about the static area of each land cover category of each study year. The increase in water body may be connected to the direction of the water waves of river Gimi which 
flow towards the plantation. The strength of the water movement encroach the plantation side. The type and nature of the rock in the study area allow outcrop of tree stands. The forest is underlain predominantly by igneous and metamorphic rocks and some other categories of rocks. The vegetation grown might have covered most part of the rock in 1998. It also appeared in 2010 rock reflectance increased. This is as a result of bush fires that engulf the forest every year, which has really affected the reflectance of the plantation that leads it to drop from $75.59 \%$ in 1998 to $48.66 \%$ in 2010 . Another change is in bare land, this is due to a new development where a Forest Research Institute in Jos took over some of these bare lands and converts them to experimental plots.

Figure 4 and 5 are representation of the table above. The green bars (right side) indicate the gain per class in hectares, while the left side define the loss of each class.

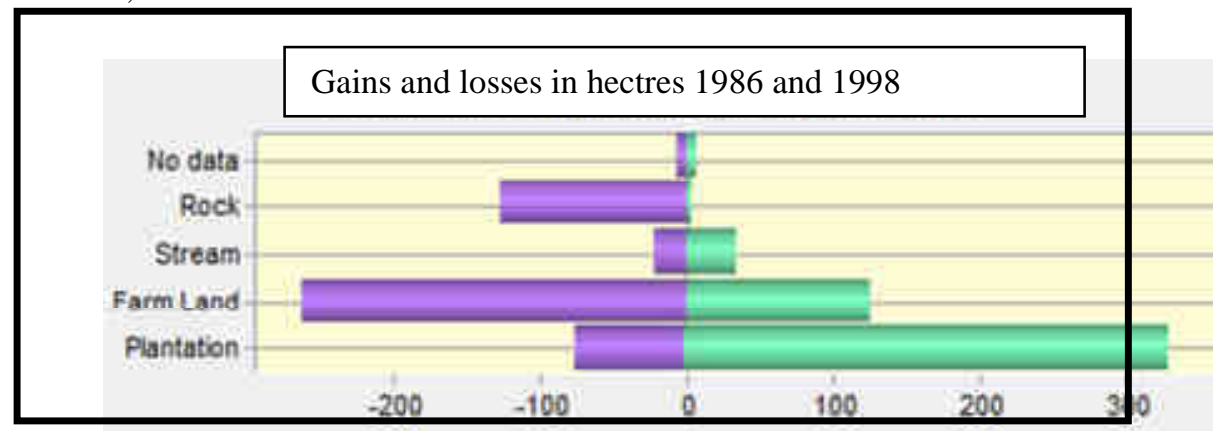

Figure 4 Gains and losses in hectares 1986-1998

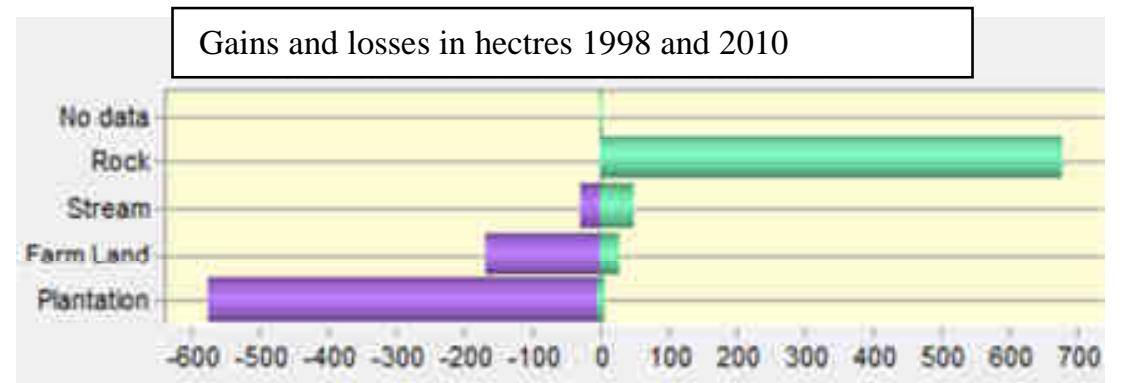

Figure 5Gains and Losses in Hectares 1998-2010

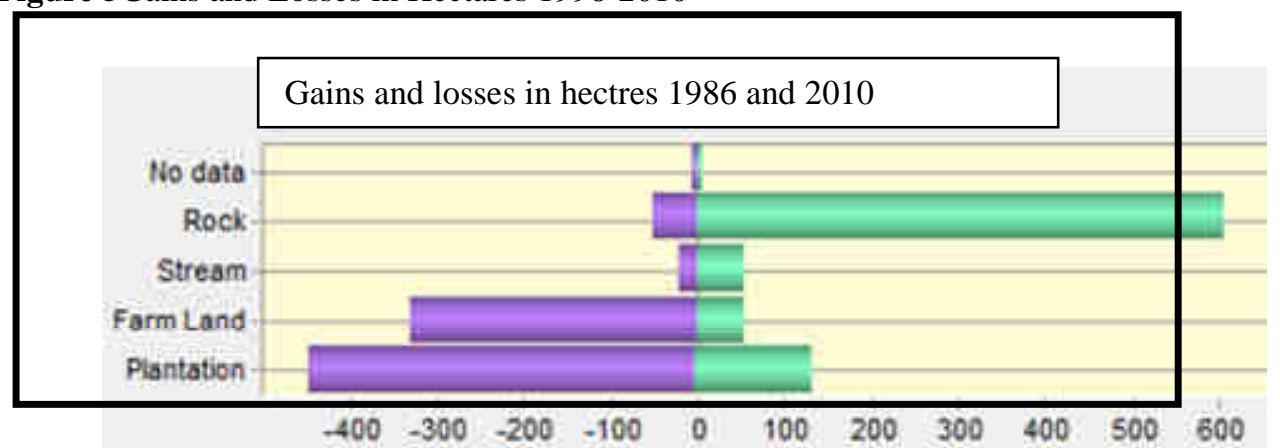

Figure 6 Gains and Losses in Hectares 1986-2010

\section{Accuracy assessment of the image}

Evaluation of classification results is an important process in satellite image classification procedure. In doing so confusion/error matrices were used. It is the most commonly employed approach for evaluating per-pixel classification (Weng,2007).

Landsat TM image (1986) was classified into six classes. It indicated an excellent overall classification $(98.55 \%)$. In classifying the second Landsat TM image (1998), an overall accuracy $(92.75 \%)$ was achieved. The third Landsat ETM image (2010) an overall accuracy (84.5\%) was achieved. The worst result and that may be attributed to the reflectance of burnt area that appeared to be rock and the loss of reflectance from some part of the plantation affected by the fire. The higher accuracy was achieved due to the utilization of more ancillary data in collecting training samples for classification and the season of the image during the process of classification. In general, there was evidence for both systematic commission and omission errors resulting from the classifier side as incorrectly commits pixel of the class being sought to other classes as well when some class on the 
ground were misidentified as another class by the classifier.

Table 5 .Error (confusion) matrix for Landsat 5 TM (17/11/1986)

\begin{tabular}{|l|l|l|l|l|l|}
\hline Classified Data & \multicolumn{5}{|c|}{ Reference data } \\
\hline & Plantation & Farm land & Stream & Bare Rock & Total \\
\hline Plantation & 489 & 0 & 0 & 0 & 489 \\
\hline Farm land & 1 & 156 & 3 & 0 & 160 \\
\hline Stream & 0 & 4 & 79 & 0 & 83 \\
\hline Bare Rock & 2 & 0 & 0 & 37 & 39 \\
\hline Total & 492 & 160 & 82 & 37 & 771 \\
\hline
\end{tabular}

Source: Field Survey 2010

\begin{tabular}{l|c|c}
\multicolumn{2}{|c|}{$\begin{array}{c}\text { Accuracy statistics } \\
\text { Class name }\end{array}$} & $\begin{array}{l}\text { user's } \\
\text { Accuracy }\end{array}$ \\
& $99.390 \%$ & Accuracy \\
\hline Plantation & $97.500 \%$ & $100 \%$ \\
Farm land & $96.341 \%$ & $97.5 \%$ \\
Stream & $100 \%$ & $95.18 \%$ \\
Bare rock & $94.87 \%$
\end{tabular}

Overall Accuracy=98.555\%

Table 6 Error (confusion) matrix for Landsat 5 TM (18/11/1998)

\begin{tabular}{|l|l|l|l|l|l|}
\hline \multicolumn{5}{|c|}{ ClassifiedData } & \multicolumn{5}{c|}{ Reference data } \\
\hline & Plantation & Farm land & Stream & Bare Rock & Total \\
\hline Plantation & 1556 & 3 & 0 & 0 & 1559 \\
\hline Farm land & 53 & 141 & 0 & 0 & 194 \\
\hline Stream & 0 & 3 & 33 & 0 & 36 \\
\hline Bare Rock & 0 & 0 & 0 & 11 & 11 \\
\hline Total & 1609 & 147 & 33 & 11 & 1800 \\
\hline
\end{tabular}

\begin{tabular}{|c|c|c|}
\hline \multicolumn{3}{|c|}{ Accuracy statistics } \\
\hline Class name & $\begin{array}{l}\text { producer's } \\
\text { Accuracy }\end{array}$ & $\begin{array}{l}\text { user's } \\
\text { Accuracy }\end{array}$ \\
\hline Plantation & $96.706 \%$ & $99.807 \%$ \\
\hline Farm land & $95.918 \%$ & $72.680 \%$ \\
\hline Water body & $100 \%$ & $91.666 \%$ \\
\hline Rock & $100 \%$ & $100 \%$ \\
\hline \multicolumn{3}{|c|}{ Overall Accuracy $=\mathbf{9 2 . 7 4 9 \%}$} \\
\hline
\end{tabular}

Table 7.Error (confusion) matrix for Landsat 5 TM (21/12/2010)

\begin{tabular}{|c|c|c|c|c|c|}
\hline ClassifiedData & \multicolumn{5}{|c|}{ Reference data } \\
\hline & Plantation & Farm land & Stream & Bare Rock & Total \\
\hline Plantation & 979 & 1 & 1 & 1 & 982 \\
\hline Farm land & 0 & 117 & 2 & 0 & 119 \\
\hline Stream & 0 & 4 & 20 & 0 & 26 \\
\hline Bare Rock & 96 & 0 & 1 & 5 & 108 \\
\hline Total & 1075 & 160 & 24 & 6 & 1235 \\
\hline
\end{tabular}

\begin{tabular}{l|r|r}
\multicolumn{2}{c}{$\begin{array}{c}\text { Accuracy statistics } \\
\text { producer's } \\
\text { Accuracy }\end{array}$} & $\begin{array}{l}\text { user's } \\
\text { Accuracy }\end{array}$ \\
\hline Plantation & $91.070 \%$ & $99.694 \%$ \\
Farm land & $73.125 \%$ & $98.319 \%$ \\
Water body & $83.333 \%$ & $76.923 \%$ \\
Rock & $83.333 \%$ & $4.630 \%$
\end{tabular}

Normalized Difference Vegetation Index (NDVI)

The Normalized Difference Vegetative Index (NDVI) is a calculation, based on several spectral bands, of the 
photosynthetic output (amount of green stuff) in a pixel in a satellite image. It measures, in effect, the amount of green vegetation in an area. In this exercise, you will use MultiSpecs ability to create new channels in an image to display the NDVI for an image.

The NDVI for a pixel is calculated from the following formula:

NIR - PAR

NDVI =

$\mathrm{NIR}+\mathrm{PAR}$

This formula yields a value that ranges from -1 (usually water) to +1 (strongest vegetative growth.) For this study NDVI calculation was performed using IDRISI NDVI algorithm to produce NDVI images for the three years.

From the maps obtained, figure 4 shows that, there was dense vegetation in 1986 with an NDVI range between 0.50 to 0.13 . That means the forest was under good control with little or no any sort of anthropogenic activities. In 1998, the NDVI result range from 0.5 to 0.25 shows that the vegetation index was very low. The last image of 2010 has an NDVI of 0.38 to -0.25 .

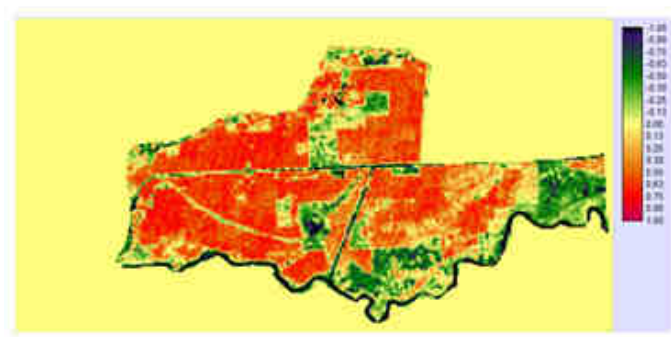

Fig 4

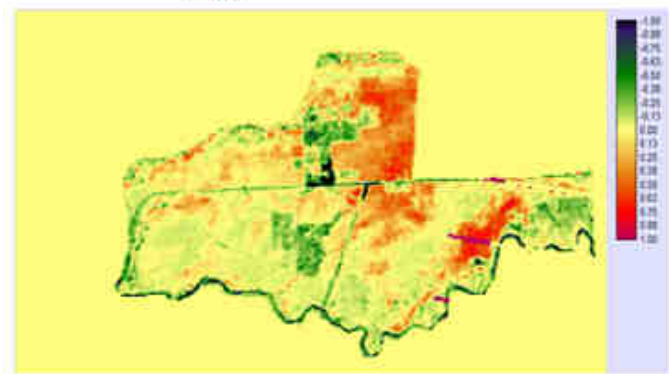

Fig 6

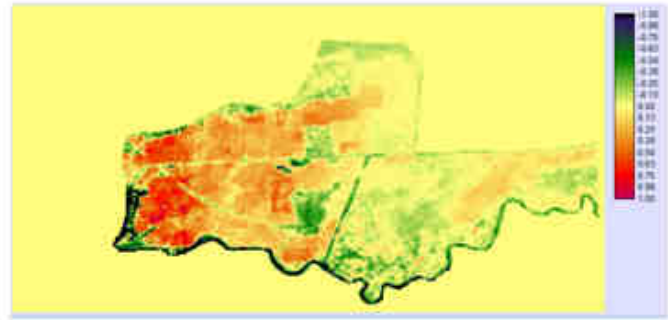

Fig 5

Fig 4 NDVI Result for Landsat-TM 1986 of the study area.

Fig 5 NDVI Result for Landsat-TM 1998 of the study area.

Fig 6 NDVI Result for Landsat-TM 2010 of the study area

Land use Land cover projection for 2037

Transition Probability Matrix

The transition probability matrix records the probability that each land cover category will change to the other category. This matrix is produced by the multiplication of each column in the transition probability matrix with the number of cells of corresponding land use in the later image. IDRISI markov algorithm was used in obtaining the result and also used for projecting changes in 2037.

Table 8 Given: Probability of changing to:

\begin{tabular}{|l|l|l|l|l|}
\hline Classes & Plantation & Bare Land & Stream & Bare Rock \\
\hline Plantation & 0.5700 & 0.0334 & 0.3210 & 0.3628 \\
\hline Bare Land & 0.2427 & 0.2817 & 0.0408 & 0.4267 \\
\hline Stream & 0.0186 & 0.3144 & 0.5334 & 0.1146 \\
\hline Bare Rock & 0.2958 & 0.1201 & 0.0410 & 0.5409 \\
\hline
\end{tabular}

\section{Markov Operation}

This is simply an operation in which the future state of a system can be modeled purely on the basis of the immediate preceding state. Markov chain analysis described land use change from one period to another and uses this as the basis to project future change. The Markov module under change/time series analysis under GIS analysis of IDRISI was used. The first image (1986) as the earlier image and the second image (2010) as the latter image was inputted. The number of time period between the two images and the number of the projected year from the second image was also inputted. Twelve years was used for both numbers of periods. 
Table 9 Land cover change prediction for 2037

\begin{tabular}{|l|l|l|l|l|l|}
\hline \multicolumn{2}{|l|}{ Land use Land cover classes } & Plantation & Bare Land & Water body & Bare Rock \\
\hline \multirow{2}{*}{$\begin{array}{l}\text { Prediction } \\
\text { Pren }\end{array}$} & Area in Hectares & 1585.26 & $\mathbf{2 1 4 . 1 1}$ & $\mathbf{9 1 . 0 8}$ & $\mathbf{2 2 0 . 0 5}$ \\
\cline { 2 - 6 } & Area in Percentage & $\mathbf{7 5 . 1 1 3 \%}$ & $\mathbf{1 0 . 1 4 7 \%}$ & $\mathbf{4 . 3 1 6 \%}$ & $\mathbf{1 0 . 4 2 6 \%}$ \\
\hline
\end{tabular}

The table above shows the statistic of land use land cover projection for 2037. Comparing the percentage representations of this table and that of table 8 , there exist similarities

In the observed distribution particularly in 1986-1998. There will be a gain in Plantation and a loss in bare land. This may be attributed to the intervention of an academic Forest institute that is converting bare land to an experiment plots. Likewise rock may be exposed at the Northern part of the forest.

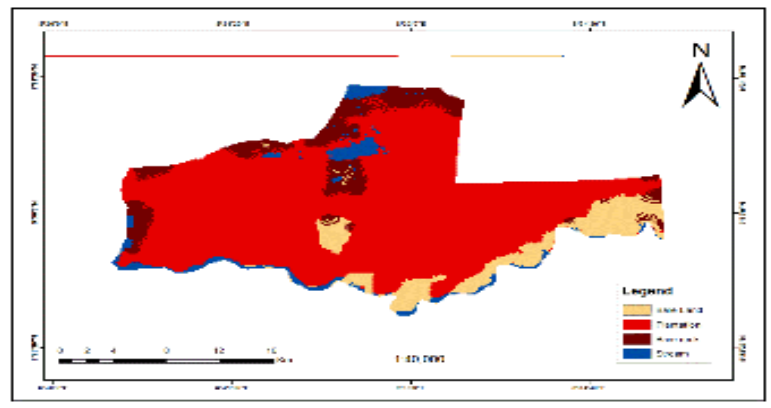

\section{CONCLUSION AND RECOMMENDATION}

The 1986, 1998TM and 2010ETM Satellite remote sensing data were used to identify, classify, assess and interpret Nimbia Forest Reserve for the year 1986, 1998 and 2010 respectively. A GIS database of land use / land cover categories and their changes within 24 years (1986-2010) was generated and analyzed. The result shows that; in general the forest plantation was retreating due to several anthropogenic activities of man such as illegal felling of wood, farming activities. The degradation can be attributed to the poor management of the forest. From this study, Landsat TM data are proved to be effective in mapping and monitoring the dynamics of land use / land cover of the study area.

\section{Recommendations}

Deforestation is not an unstoppable or irreversible process. Increased and concerted efforts in forestplantation 'rebirth' and rejuvenation will bring to use the type of forest reserve we envisaged. In order to reducethe effects of deforestation in in Nimbia Forest Reserve the study offer the following recommendations:

i. Government by way of policy should be strict in preserving forest reserves from illegal occupation.

ii. The forest management should reclaim and replant every cleared surface within the forest.

iii. Employment of more personnel and provision of attractive remunerations to staff.

vi. Trees should be allowed meet required maturity before felling.

v. Lastly, the need to train the policy makers and resource managers on land use and land cover information through remote sensing and GIS. This will help in easily realizing where action should be taken and what kinds of intervention are needed.

\section{REFERENCES}

Akindele, S. (1991). Development of Site Index equation for Teak plantation in Southwestern Nigeria. Akure: Dept. of Forestry anf Wood technology, Federal University of Technology, Akure, Nigeria.

Ayuba, S. M. (2006). Dissertation. In an evaluation of soil properties and development under Teak(tecton grandis linn F.) (p. 36). Zaria: Ahmadu Bello University.

Ball, J. P. (1999). Global Overview of Teak Plantation. Technology and Productivity of Teak Plantation.

CBD., Convention on Biological Diversity. (2001). The Value of Forest Ecosystems. Montreal: CBD Technical Series.

Celik, P. D. (2006). Forest and Nutural Disasters. Istanbul: Fuculty of Forestry,University of Istanbul, Turkey.

Chuvieco, E. A. (2010). Fundamental of satellite remote sensing. New York: Taylor and Francis group.

CIFOR. (2003). National and International Policies to Control Illegal Forest Activities .Dept. of Forest Economy, Ministry of Foreign Affairs,Japan.

Congalton, R. A. (1999). Assessing the accuracy of remotely sensed data. Principles and practices. . Boca Raton, Florida.: Lewis Publishers,.

Coppin, P. \&. (1996). Digital change detection in Forest ecosystems with remote sensing imagery. Remote sensing review, vol.13 p. 207-234.

Cunningham, L. (1998). Inventory New York;s land use and nutural resources. new York's Food and Life 
Sciences, vol.3, no. 4, p 4-7.

David, W. P. (2001). The Economic value of Forest ecosystems CSERGE-Economics. University college London: Blackwell science inc.

Deer, J. (1995). Digital change detection techniques:civilian and military applications. Australia: Defence science and technology organization.

Dewan, A. M. (2009). Land use and land cover change in greaterDhaka, Bangladesh: Using remote sensing to promote sustainable urbanization. Applied Geography,, 29 (3): 390-401

Diaz, S. (2006). "Biodiversity Loss Threaten Human Well-Being". PLOS Biology.

Dr. mehmet misir, A. P. (1997). The Role of GIS in Multi- Objective Forest Planning.

Ehiagbanare, J. (2007). Economic contribution of the Forest to the Economy of Edo State,Nigeria. Okada: Igbinedion university.

EOSAT. (1994). Statewide Purchase plan keep south Carolina Residents in the know,in EOSAT Notes. Lanhan, MD: EOSAT Company .

ERDAS. (1992). Wetlands in EOSAT Data User Notes. Lanhan,MD: EOSAT Company.

Foody, G. (2002). statua of Land Cover Classification accuracy assessment. Remote Sensing of Environment, 80:185-201.

Gibson, P. A. (2000). Introductory Remote sensing:Digital Image Processing and Applications. Routeledge.

Giridhar, M. V. (2008). Evaluation of watershed parameters using RS and GIS. 11th Aerospace Division International Conference on Engineering, Science, Construction, and Operations in Challenging Environments (p. 323). Earth and Space Conference.

Hassan, E. A. (2010). Integration of Remote Sensing and GIS in the study of Vegetation Trends and Conditions in the Gum Arabic Belt. Sudan: North Kurdofani.

Inc., E. (1992). Map State of Geogia DNR in the Monitor. Atlanta: ERDAS Inc.

Ishmael, J.D. (2006). action sheet 47.Tropical Moist Forest Silviculture and Management: A history of success and failure. CAB International, Wallingford, $359 \mathrm{pp}$.

Ivan bermejo, I. C. (2003). Growth and yield for Teak in Costa Rica. Madrid, Spain: Centre for Forest Resaearch INIA.

Jensen, J. (1996). Introductory Digital Image Processing: A remote sensing perspective(2nd Edition). Eaglewood cliffs,New Jersey: Prentice-Hall.

Krieger, D. J. (2001). The Economic Value of Forest Ecosystems Services: A Review. The wilderness society.

Lambin. (1996). Change detection multiple temporal scales. Seosonal and annual variationin landscape variables.Photogrammtry eng. Rem Sens., 931-938.

Lazaro, R. F. (2001). Analysis of 30 years Rainfall record(1967-1997) in semi-arid SE spain for implications on Vegetation. Journal of Arid Environment, 48: 373-395.

Lillesand, T. K. (2004). Remote sensing and image Interpretation, Fifth edition. New York: john wiley and sons. Longley, P. D. (2001). Reomte Sensing and urban Analysis. London: Tylor and Francis.

Lu, D. M. (2004). Change Detection Techniques. International journal of remote sensing, 25(12): 351-364.

Lucca Tacconi, M. B. (2003). National and international policies to control Illegal Forest activities . Japan: Ministry of Foreign Affairs.

Lunette, R. A. (1999). Application, Project Formulation and analytical Approach. Remote Sensing Change Detection. Environmental monitoring \& Application (pp. 1-20). London:Tylor \& Francis.

Macleod, C. (1998). A Quantitative comparison of Change Detection Algorithms for Monitoring Ealgrass from remotely sensed data. Photogrammetry Engineering \& Remote Sensing, Vol. 64 No. 3, 207-216.

Malinverni, E. F. (2003). Spatia Modeling in a GIS for an Environment decision support system. Spatial Analysis and Decision making SADM2003 (pp. 229-241). Hong Kong: Commission II WG 5 and 6.

Neil Adger, K. B. (1994). Towarda Estimating total Economic value of Forest in Mexico. Center for Social and Economic Research on the Global Environment.

Obidike, E. O. (2011). Msc Thesis. In Assessment of heterogeneity in soil properties of Nimbia forest resrve in southern guinea savanna of nigeria for site specific management (p. 20). Zaria: Ahmadu bello University.

Plaza, A. A. (2008). High performance computing in remote sensing. Taylor and francis Group, LLC.

Pomery, D. (2004). The state of Uganda's Biodiversity. Kampala: Makerere University.

Ramachandra, T. K. (2004). Geographic Decision Support System for Land use, Land cover Dynamics Analysis. FOSS/GRASS Users Conference. Bangkok, Thailand.

Rindfuss, R. E. (2002). Linking people, place and policy: A GIS science approach. Boston.: Kluwer Academic Press.

Roif A. de By (ed), R. A.J. (2001). Principles of Geographic Information systems-An introductory rext book. ITC Educational Text books series.

Shoshany, M. A. (1994). Monitoring Temporal Vegetation Cover change in miditerranean and Arid Ecosystems Using a Remote sensing Techniques:A case study of the judean mountain and the judean desert. journal of 
Arid Environment, 33: 9-21.

Singh, A. (1989). Digital Change Detection Techniques Using Remotely Sensed Data. International Journal of Remote Sensing, Vol. 10, No. 6, 989.

Tanaka, N. H. (1998). Distribution, Growth and Site requirment of Teak. JARQ 32.

Tewari, D. (1992). Monograph of Reak (tectona grandis). Dehran dun, India: International book Distributors.

Tottrup, C. (2004). Mapping long-term changes in savannah crop productivity in Senegal through trend analysis of time series of remote sensing data.Agriculture. Ecosystems and Environment, pp. 103.

Tudunwada, I. Y. ( 2012). Vegetation Change Detection due to Anthropogenic activities In Falgore Game Reserve,Kano State, Nigeria. International Conference Geotunis 6th session.

Usman, B. A. (2010). Nigerian Forestry,wildlife and Protected Areas. Ilorin: Dept. of Geography, University of Ilorin.

Uzay, K. A. (2009). The Spatial-temporal Forest cover changes in koprulu canyon National park in Turkey. Trabzon,Turkey: Kuradeniz technical University,Fuculty of Forestry.

Wilson, J. P. (2008). The hand book of geographic information science. Victoria, Australia: Blackwell publishing.

Yuan, D. A. (1998). NALC land cover change detection pilot study:Washington D.C Area Experiments,Remote Sensing of Environment. Washington.

Zhiliang, C. X. (2008). Landuse/cover changes between 1990 and 2000 based on remote sensing and GIS in. The International Society for Optical Engineering. China: Proceedings of SPIE. 
The IISTE is a pioneer in the Open-Access hosting service and academic event management. The aim of the firm is Accelerating Global Knowledge Sharing.

More information about the firm can be found on the homepage:

http://www.iiste.org

\section{CALL FOR JOURNAL PAPERS}

There are more than 30 peer-reviewed academic journals hosted under the hosting platform.

Prospective authors of journals can find the submission instruction on the following page: http://www.iiste.org/journals/ All the journals articles are available online to the readers all over the world without financial, legal, or technical barriers other than those inseparable from gaining access to the internet itself. Paper version of the journals is also available upon request of readers and authors.

\section{MORE RESOURCES}

Book publication information: http://www.iiste.org/book/

\section{IISTE Knowledge Sharing Partners}

EBSCO, Index Copernicus, Ulrich's Periodicals Directory, JournalTOCS, PKP Open Archives Harvester, Bielefeld Academic Search Engine, Elektronische Zeitschriftenbibliothek EZB, Open J-Gate, OCLC WorldCat, Universe Digtial Library, NewJour, Google Scholar

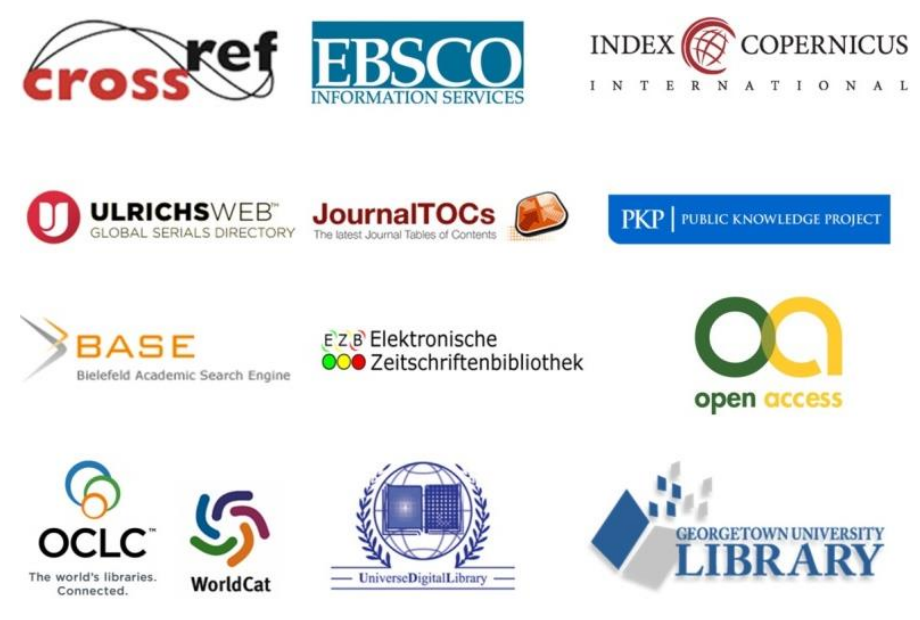

